\title{
Non Alcoholic Fatty Liver Disease- An Ayurvedic Pragmatic Approach with Its Management
}

\author{
${ }^{1}$ Remya. E, ${ }^{2}$ Mandip Goyal \\ ${ }^{1}$ PhD Scholar Dept. of Kayachikitsa, IPGT \& RA, Gujarat Ayurved University, Jamnagar - 361008. \\ ${ }^{2}$ Asso. Professor, Dept. of Kayachikitsa, IPGT \& RA, Gujarat Ayurved University, Jamnagar - 361008. \\ Corresponding Author: Remya. E \\ PhD Scholar Dept. of Kayachikitsa, IPGT \& RA, Gujarat Ayurved University, Jamnagar - 361008.
}

\begin{abstract}
:
The term Non-alcoholic Fatty Liver Disease (NAFLD) refers to a broad spectrum of disorders characterized by fatty infiltration of the liver, steatosis, steatohepatitis, and cirrhosis. Epidemiological studies suggest prevalence of NAFLD in around 9\% to 32\% of general population in India with a higher prevalence in those with obesity and diabetes. No established pharmacological treatment is available for NAFLD in conventional medical science. Several empirical treatment strategies such as dietary restriction, physical exercise and weight reduction form the first line of treatment. Ayurveda has immense potential in the management of Non-Communicable Diseases, and NAFLD is one among them. Purpose of the present study was to formulate a practical Ayurvedic protocol for the management of NAFLD. Ayurvedic classics, compendia, clinical medicine texts \& related websites were consulted and reviewed for the present work. In the initial stage of NAFLD, Kapha Medo Dushti occurs. When Pitta gets involved in the pathogenesis, inflammatory changes occur which leads to the next stage of the disease, ie. Non-Alcoholic Steato Hepatitis (NASH). When Vata comes into the picture, fibrosis occurs which may end up in Cirrhosis. The management should be the breakdown of pathological factors like Agnivaigunya, Srotorodha and Kaphamedodushti. A practical treatment protocol including Purgation, Pacification and Lifestyle modification with due importance to particular bodily constitution can help in the proper management of the disease. Through the proper administration of Ayurvedic treatment protocol along with lifestyle modification, progression of the disease and further complications can be prevented upto a great extent.
\end{abstract}

Key words : Non-Alcoholic Fatty Liver Disease, Non-Alcoholic Steato- Hepatitis, Sthoulya, Yakrit

\section{Introduction}

Liver is the largest gland and heaviest organ in the body, weighing about 1200-1500gm in adults. It is situated in the abdominal cavity below the diaphragm mainly in the right hypochondrium, extending across the epigastrium to the left hypochondrium. It is an extremely vascular organ, which receives about $30 \%$ of resting cardiac output. Liver is an essential organ of the body, which acts as a well equipped biochemical laboratory where practically metabolism of all the nutritional substances takes place. Liver is the commonest site for accumulation of fat because it plays central role in fat metabolism. Depending upon the cause and amount of accumulation, fatty change may be mild and reversible, or severe producing irreversible cell injury and cell death. Disturbances of lipid metabolism in liver due to various etiological factors lead to Fatty Liver. 


\section{${ }^{1}$ Remya. E, International Journal of Ayurvedic\& Herbal Medicine 7(6) Nov.-Dec. 2017 (2948-2955)}

Fatty liver is a reversible condition wherein large amount of fat accumulate in liver cells via the process of steatosis. When fat content exceeds $5 \%$ of total weight of liver or more than $30 \%$ of liver cells in a liver lobule are with fat deposit, this condition is called as Fatty Liver. Etiology of Fatty Liver mainly falls under two categories (Table No:1). First category comprises the conditions with excess fat which imparts increased workload to liver for metabolizing fat. Second category involves conditions of liver cell damage in which fat cannot be metabolized due to liver cell injury

Conditions with excess fat usually manifest as Non - Alcoholic Fatty Liver Disease (NAFLD). It is the Hepatic complication of Metabolic Syndrome which occurs when fat is deposited in the liver due to causes other than excessive alcohol use. NAFLD is an umbrella term for a range of liver disorders characterized by macro vesicular hepatic fat accumulation (steatosis), signs of hepatocyte injury, mixed inflammatory cell infiltrate and variable hepatic fibrosis leading to cirrhosis. NAFLD itself has benign prognosis, but Non - Alcoholic Steato-Hepatitis (NASH) is a potentially serious form of NAFLD, marked by liver inflammation, which may progress to scarring \& irreversible damage. Approximately, $20 \%$ to $30 \%$ of adults in the general population in western countries have NAFLD and its prevalence increases to $70 \%$ to $90 \%$ among persons who or obese or have diabetes. NASH can progress to cirrhosis and end-stage liver disease and is projected to be the leading cause of liver transplantation by 2020. NAFLD is overall associated with an increased cardio metabolic risk. (API - page no 885 Introduction)

NAFLD is a disease of affluent societies which increases in prevalence in proportion to the rise in obesity. It has become the most common cause of chronic liver disease after Hepatitis $\mathrm{B}$, hepatitis $\mathrm{C}$ and alcohol. (Davidson) The prevalence of NAFLD has increased over last few years. The global epidemic of obesity and diabetes in all age groups may be partly responsible for the increase. Urbanisation and associated changes such as sedentary lifestyle, fat rich diet and a higher inherited tendency for Diabetes mellitus make Indians more prone to Metabolic Syndrome or insulin resistance and its manifestations, such as NAFLD and NASH. The majority have one or more risk factors for metabolic syndrome, such as Diabetes mellitus, obesity, hypertension or hyperlipidaemia. The risk of NAFLD was the highest in those with BMI $>25 \mathrm{~kg} / \mathrm{m}^{2}$. Both Fatty Liver and NASH have been reported in all age groups, including children, with highest prevalence in the age group of 40-49 years, with equal frequency in males and females ${ }^{\mathrm{i}}$. (API 885 Epidemiology)

\section{Aims and Objectives}

1. To define NAFLD in terms of Ayurvedic perspective

2. To formulate a practical Ayurvedic protocol for the management of NAFLD

\section{Materials and Method}

Ayurvedic classics, compendia, clinical medicine texts \& related websites were consulted and reviewed for the present work.

\section{Etio-pathogenesis - Modern and Ayurvedic Perspective}

Liver can be compared with Yakrit mentioned in Ayurvedic classics. Yakrit is the seat of Ranjaka pittawhich transforms Apya Rasa Dhatu to Rakta Dhatu. It is the Mulasthana (site of origin) of Raktavahasrotas; also related to Raktavahi \& Mamsavahi Dhamani. Yakrit is an important Koshthanga, which intimately related to Rasa, Rakta and Mamsa Dhatus and plays an important role in Dhatu Parinama.

Heavy fat rich diet, junk food, soft drinks, sedentary lifestyle, Metabolic syndrome (Obesity, Diabetes Mellitus, Dyslipidaemia), drugs (eg: Cortico steroids, Aspirin, Tetracyclin) etc. are considered to be the major etiological factors of NAFLD. Etiology of Fatty Liver has been discussed in Table No:1. As per Ayurvedic concept, heavy fat rich diet, soft drinks and sedentary lifestyle are responsible for the dushti of 
${ }^{1}$ Remya. E, International Journal of Ayurvedic\& Herbal Medicine 7(6) Nov.-Dec. 2017 (2948-2955)

Annavaha, Udakavaha, Rasavaha, Raktavaha, Medovaha and Pureeshavaha Srotas (Caraka). Ajirna (Indigestion), Sthaulya (Obesity) and Prameha (Diabetes Mellitus) which occurs due to the vitiation of Annavaha, Rasavaha and Medovaha Srotas acts as Nidanarthakara Rogas (Diseases which cause another diseases) which may result in the manifestation of Fatty Liver.

Several mechanisms have been postulated to explain the pathogenesis of NASH. The currently favoured is 'Multiple Hit Hypothesis' ${ }^{\text {i }}$. The current two- hit hypothesis explains why not everyone with fatty liver disease develops hepatic fibrosis. The 'first hit' results in steatosis ( fatty liver), which is only complicated by inflammation if a 'second hit' occurs. Leptin, which is an appetite reducer and a fibrogenic in vitro, is probably then needed to cause hepatic fibrosis. The components of first hit include release of free fatty acids from central adipose tissue, along with adipokines, drain into the portal vein as well as causing insulin resistance. These processes result in reduced hepatic fatty acid oxidation and increased fatty acid synthesis. Pathogenesis of Fatty Liver has been depicted in Figure No:1.

Fatty liver occurs as a result of increased fat import into hepatocytes and reduced fat export. Insulin resistance causes hepatic steatosis, which also perpetuates insulin resistance. Subsequent activation of TNF - alpha, oxidant stress through the production of reactive oxygen species and production of endotoxin then result in inflammation and eventually fibrosis. Factors including leptin are probably needed for fibrosis ${ }^{\text {vii }}$.

NAFLD is a Santarpanajanya Vyadhi (Disease cause by over nourishment) having Nidana (Etiology) and Samprapti (Pathogenesis) similar to Sthaulya. Initial pathology lies at Agnivikruti (Vitiation of digestive mechanism) which leads to the formation of Apakva Anna Rasa (Improperly formed digestive end product) which again leads to the vitiation of Kaphadosha and unequal formation and deposit of Meda (fat tissue) in Yakrit. This condition is called as Fatty Liver. Vitiated Kapha and Meda results in Srotorodha (blockage of channels) which provokes Vata. Vitiated Vata again results in Agnivikruti and this cycle repeats.

When Pitta gets involved in the pathogenesis, hepatocytes have inflammatory changes and the disease progresses to the next stage ie. NASH. When Vata comes into the picture, fibrosis occurs and the condition may progress to its drastic end stages Cirrhosis, Ascites, Hepato cellular Carcinoma and also pave way to other metabolic complications. Major factors responsible for the etio-pathogenesis of NAFLD include vitiation of Samanavayu, Apanavayu, Pachakapitta, Ranjakapitta, Kledaka kapha, Rasa Rakta Medo dhatu and Pureesha. Annavaha, Udakavaha, Rasavaha, Raktavaha, Medovaha and Pureeshavaha are the Srotas involved in the causation and manifestation of NAFLD.

\section{Clinical Presentation}

Most patients with NAFLD are asymptomatic. Diagnosis most often follows incidental detection of raised liver enzymes or of Fatty Liver on ultrasound. These abnormalities are usually picked up during evaluation for dyspepsia, malaise or fatiguability, prior to medical procedures like organ donation or routine health examination. A smaller fraction of patients experience symptoms indicative of more serious liver diseases and may develop pruritus, anorexia and nausea. The development of ascites, anasacra, variceal haemorrhage or symptoms of hepatic encephalopathy indicates decompensated cirrhosis. Jaundice occurs late in the course of NASH and indicates advanced liver disease. No specific symptoms can distinguish NAFLD or NASH from other type of liver diseases. The majority of patients have one or more risk factors for metabolic syndrome, such as type 2 Diabetes, obesity, hypertension or hyperlipidaemia. Clinical examination is often unremarkable though nearly half the patients have mild hepatomegaly. Jaundice or signs of liver failure are absent $^{\mathrm{i}}$.

Mainly NAFLD has two types of presentations

1. Obese NAFLD : Fatty liver in obese people which is more common and having better prognosis

2. Lean NAFLD : Fatty Liver in lean people, less common but comparatively worse prognosis 
${ }^{1}$ Remya. E, International Journal of Ayurvedic\& Herbal Medicine 7(6) Nov.-Dec. 2017 (2948-2955)

In the initial stage of NAFLD, patients present with heaviness and distention of abdomen, increased or decreased appetite, constipation or diarrhea, malaise and belching. This condition can be clearly compared wit Ajirna. In obese persons, the presentation exactly resembles with that of Sthaulya. When NAFLD progress to next stage, clinical profile of NASH is persistently similar with Amlapitta (Gasto - eosophageal Reflex Disease) in which patients present with sour eructation, burning sensation of chest and abdomen, distention of abdomen, tastelessness and loose stools. Patient may pass stools frequently without proper digestion as in Grahani (Sprue). When the condition progresses to Fibrosis and Cirrhosis, systemic features indicative of more serious liver disorders such as Pandu (Anaemia, Fatigue, Altered sensorium), Kamala (yellowish sclera, skin \& urine), Raktapitta (haematemesis) will be more evident. Finally, it ends up in one among Ashtamahagada (8 major diseases) ie. Udara (Ascites); Yakriddalyudara is being more site specific.

\section{Diagnosis}

Diagnosis of NAFLD is strongly suggested when metabolic syndrome is present and other specific etiologies of liver disease and excessive alcoholic consumption (>20g/day) have been excluded. It should be suspected as a cause of asymptomatic elevation of amino transferases, although it can be presented with normal or fluctuating aspartate aminotransferases (AST) and alanine aminotransferases (ALT) ${ }^{\mathrm{i}}$. or isolated elevation of Gamma Glutamyl Transpeptidases(GGT). Unfortunately, there is no single diagnostic blood test. ALT is normally higher than AST. Elevated ALP levels are seen in about $30 \%$ of cases. It is important to differentiate NAFLD, which does not require follow-up, from NASH. Elevated serum transaminases greater than twice the upper limit of normal and the presence of the metabolic syndrome are useful predictors of $\mathrm{NASH}^{\mathrm{vii}}$.

Ultrasound may show liver steatosis as a hyper echogenic image, ie. 'bright liver'. Radiologic techniques used to evaluate NAFLD include ultrasound, computed tomography (CT), magnetic resonance imaging (MRI), magnetic resonance spectroscopy(MRS) and fibroscan ( tissue elastography). These radiologic modalities are accurate in detecting moderate to severe hepatic steatosis and none is able to distinguish simple steatosis from NASH or to determine the stage of hepatic fibrosis. Liver biopsy is diagnostic, but may not be routinely required. It allows semi- quantitative assessment of fat deposition and associated necro- inflammation and fibrosis. Typical histologic features of NAFLD predominate in perivenular regions, ie. Zone of 3 hepatic acinus and include the presence of macro-vesicular steatosis, lobular neutrophilic inflammation, presence of Mallory bodies, ballooning degeneration, lipogranuloma and pericellular fibrosis.

\section{Treatment}

There is no established treatment for NAFLD in conventional medical science. Treatment is usually directed towards optimizing body weight, which is safe and improves histological disease activity in NASH. Initial approach involves dietary modification based on metabolic profile (obesity, diabetes, hyperlipidemia, hypertension) and getting patients to increased levels of physical activity. Even small changes in body weight $(0.5$ to $3 \mathrm{~kg})$ can achieve improvement in histological changes and reversal of insulin resistance. Various other treatment modalities used for NAFLD have included treatment for risk factors like diabetes mellitus and hyperlipidaemia, and use of insulin sensitizing agents such as biguanides (metformin), thiazolidinediones ( rosiglitazone, pioglitazone), antioxidants and various hepato protective agents. Other agents like pentoxifylline, telmisartan, L- carnitine and vitamin $\mathrm{E}$ are being evaluated.

NAFLD is an increasingly recognized clinico-pathological condition that may progress to end stage liver disease. The clinical implications of NAFLD are derived mostly from its common occurrence in the general population, as well as its potential to progress to cirrhosis and liver failure. No established pharmacological treatment is available for NAFLD in modern medicine. Treatment of NAFLD is still 
${ }^{1}$ Remya. E, International Journal of Ayurvedic\& Herbal Medicine 7(6) Nov.-Dec. 2017 (2948-2955)

evolving, with no single drug clearly shown to be effective. Several empiric treatment strategies such as dietary restriction, physical exercise and weight reduction form the first line of treatment. Hence, there is a search for alternative treatment modalities in other systems of medicine, which is safe and cost-effective. Ayurveda has immense potential in the management of Non-Communicable Diseases, and NAFLD is one among them.

Points to be focused in the treatment of NAFLD are Agnivikruti, vitiation of Kapha and Meda at the Mula Sthana of Raktavaha Srotasa, Srotorodha and vitiation of Vata. Agnideepana (Stimulation of digestive fire), Rookshana (Dryness therapy), Srotosodhana (Removal of blockage of channels) , pacification of Kapha, Meda and Vata should be the first line of treatment in the management of Fatty Liver. Here, the treatment principle adopted is almost similar to that of Sthaulya. When Fatty Liver progresses to next stage and Dhatus get involved, treatment should be directed towards Prasadana (Purification) of Rasa and Rakta and also Yakritshothahara (Relieves hepatic inflammation)). Judicious administration of all the four limbs of treatment ie. Samsodhana, Samshamana, Ahara and Achara will help in the reversal of fatty changes of liver and prevention of further complications.

Virechana is the most suitable Shodhana Karma in Liver disorders. . It is considered as the best remedy for Pittaja \& Raktaja Roga and also for GIT disorders like Gulma, Arsha(Haemorrhoids), Kamala (Jaundice), Chardhi (Vomiting), Pleeha (Disorders of spleen), Pakwasaya Vyatha(Disorders of Large Intestine), Koshthaga krumi (Intestinal worms), Shakrit Graha (Constipation). It is Indicated in excessive Dosha accumulation \& Srotorodha. It acts as Agnideepana and Srotoshodhana. Different Churna, Taila, Ghrita, Avaleha preparations mentioned in classical texts and available in markets are widely used for this purpose. Churnas like Patoladi, Hapushadi, Narayana, Avipatti, different preparations of Erandataila, Trivrit Avaleha, Misraka sneha, Haritakyadi ghrita can be used judiciously for this purpose.

While coming to Shamana chikitsa, single herbs like Sharapunkha, Bhoomiamalaki, Katuki, Guduchi, Haritaki, Vasa and Pippali can be used safely for the effective management of NAFLD. All these drugs are proven hepato - protectives in experimental and clinical trials. Formulations like Kashaya (Vasaguduchyadi, Phalatrikadi, Drakshadi, Patola Katurohinyadi), Arishta (Sudarshanaarishta, Rohitakarishta, Pippalyasava), Churna (Hinguvachadi, Vaiswanara), Herbo- mineral preparations (Abhraka Bhasma, Arogyavardhini Rasa, Punarnava Mandoora) are well known for their hepatoprotective, hypolipidaemics and haematinic properties, and can be effectively used for the management of NAFLD.

Disharmony in the relationship between human being and ecosystem is the major causative factor of all diseases especially Metabolic syndrome, which mainly arises out of faulty diet and lifestyle. Therefore, diet and lifestyle have a major role in the causation, prevention and management of NAFLD. Diet should be modified as per 'Eight Rules of Eating' by Acharya Caraka. Yoga and Pranayama can be included in the daily routine for better results. Pathyapathya which can be advised to the patient during the course of the therapy has been discussed in Table No:2

\section{Conclusion}

NAFLD is an increasingly recognized clinico-pathological condition that may progress to end stage liver disease in which the conventional medicine fails to establish effective management strategy. Ayurvedic treatment modalities have immense potential in the management of these kind of lifestyle disorders. As per Ayurvedic concepts, Agni, Kapha, Vata dosha, Anna vaha Srotasa, Rasa, Rakta, Meda Dhatu \& Srotasa, Yakrit are the cornerstones of Samprapti of Non-Alcoholic Fatty Liver Disease. . A practical treatment protocol including Virechana, Shamanoushadha and Pathyasevana with due importance to particular bodily constitution can help in the proper management of the disease. Through the proper administration of 
${ }^{1}$ Remya. E, International Journal of Ayurvedic\& Herbal Medicine 7(6) Nov.-Dec. 2017 (2948-2955)

Ayurvedic treatment protocol along with lifestyle modification, progression of the disease and further complications can be prevented upto a great extent.

\section{References}

1. Yogesh K Chawla, Sunil Taneja, API Textbook Of Medicine, 9th Edition, , Vol. 1, Sec. 14, Ch. 11, Jaypee Brothers Medical Publishers (P) Ltd., 2012, p. 885

2. J.D.Collier, G. Webster, Davidson's Principles and Practise of Medicine, 21st Edition, Part 2, Ch. 23, Churchill Livingstone Elsevier, 2010, p. 956-957

3. Vaidya Jadavji Trikamji Acharya, Editor, Susruta Samhita of Susruta, Sutrasthana, Ch. 14, Ver 4 , Chaukhambha Sanskrit Sansthan, Varanasi, Reprint 2013, p.59

4. Vaidya Jadavji Trikamji Acharya, Editor, Susruta Samhita of Susruta, Sareerasthana, Ch. 9, Ver 12 , Chaukhambha Sanskrit Sansthan, Varanasi, Reprint 2013, p.386

5. Pt. Hari Sadasiva Sastri Paradakara, Editor, Ashtanga Hridaya of Vagbhata, Reprint Edition, , Sareerasthana, Ch. 3, Ver. 12, Chaukhambha Sanskrit Sansthan, Varanasi, 2012, p. 387

6. Vaidya Jadavji Trikamji Acharya, Editor, Charaka Samhita of Charaka, Reprint Edition, Vimanasthana, Ch. 5, Ver. 11-15,21, Chaukhambha Orientalia, Varanasi, 2011, p. 251-252

7. J.D.Collier, G. Webster, Davidson's Principles and Practise of Medicine, 21st Edition, Part 2, Chapter 23, Churchill Livingstone Elsevier , 2010, Page no: 957

8. Vaidya Jadavji Trikamji, Editor, Madhava nidana by Madhavakara, 6th edition Amlapitta nidana, Ver. 2-3, Chaukhambha Orientalia, Varanasi, 2001, p. 292

9. Pt. Hari Sadasiva Sastri Paradakara, Editor, Ashtanga Hridaya of Vagbhata, Reprint Edition, Nidanasthana, Ch. 8, Ver. 17 - 18, Chaukhambha Sanskrit Sansthan, Varanasi, 2012, p. 497

10. Pt. Hari Sadasiva Sastri Paradakara, Editor, Ashtanga Hridaya of Vagbhata, Reprint Edition, , Nidanasthana, Ch. 13, Ver. 3-6, Chaukhambha Sanskrit Sansthan, Varanasi, 2012, p.517-518

11. Pt. Hari Sadasiva Sastri Paradakara, Editor, Ashtanga Hridaya of Vagbhata, Reprint Edition, , Nidanasthana, Ch. 13, Ver. 16, Chaukhambha Sanskrit Sansthan, Varanasi, 2012, p.517-519

12. Pt. Hari Sadasiva Sastri Paradakara, Editor, Ashtanga Hridaya of Vagbhata, Reprint Edition, , Nidanasthana, Ch. 3, Ver. 7, Chaukhambha Sanskrit Sansthan, Varanasi, 2012, p.467

13. Pt. Hari Sadasiva Sastri Paradakara, Editor, Ashtanga Hridaya of Vagbhata, Reprint Edition, , Nidanasthana, Ch. 12, Ver. 27, Chaukhambha Sanskrit Sansthan, Varanasi, 2012, p.517-515

14. Yogesh K Chawla, Sunil Taneja, API Textbook Of Medicine, 9th Edition, , Vol. 1, Sec. 14, Ch. 11, Jaypee Brothers Medical Publishers (P) Ltd., 2012, p. 886

15. Yogesh K Chawla, Sunil Taneja, API Textbook Of Medicine, 9th Edition, , Vol. 1, Sec. 14, Ch. 11, Jaypee Brothers Medical Publishers (P) Ltd., 2012, p. 886-887

16. Pt. Hari Sadasiva Sastri Paradakara, Editor, Ashtanga Hridaya of Vagbhata, Reprint Edition, , Sutrasthana, Ch. 14, Ver. 21, Chaukhambha Sanskrit Sansthan, Varanasi, 2012, p.226

17. Pt. Hari Sadasiva Sastri Paradakara, Editor, Ashtanga Hridaya of Vagbhata, Reprint Edition, , Sutrasthana, Ch. 18, Ver. 8-10, Chaukhambha Sanskrit Sansthan, Varanasi, 2012, p.261

18. Vaidya Jadavji Trikamji Acharya, Charaka Samhita of Charaka, Reprint Edition, Vimanasthana, Ch. 1, Ver. 21, Chaukhambha Orientalia, Varanasi, 2011, p. 235 
${ }^{1}$ Remya. E, International Journal of Ayurvedic\& Herbal Medicine 7(6) Nov.-Dec. 2017 (2948-2955)

\section{$\underline{\text { Figures }}$}

\section{NORMAL LIVER}

DIET

仓FA INFLUX

תFA OXIDATION

FIRST HIT $\quad$ iFA SYNTHESIS

\VLDL ASSEMBLY

INSULIN RESISTANCE

\section{FATTY LIVER}

TNF - ALPHA

OXIDANT STRESS

SECOND HIT ENDOTOXIN

IMMUNE FACTORS

\section{NASH}

Љֶ OTHER FACTORS EG: LEPTIN

\section{FIBROSIS}

Figure No:1 Pathogenesis of Fatty Liver

\section{$\underline{\text { Tables }}$}

Table No:1 Etiology of Fatty Liver

\begin{tabular}{|l|l|}
\hline \multicolumn{1}{|c|}{ Conditions with excess fat } & \multicolumn{1}{|c|}{ Liver cell damage } \\
\hline Obesity & $\begin{array}{l}\text { Alcoholic Liver Disease ( most } \\
\text { common) }\end{array}$ \\
\hline Diabetes mellitus & Starvation \\
\hline Congenital hyperlipidaemia & Protein calorie malnutrition \\
\hline & Chronic illness (e.g. TB) \\
\hline & Acute fatty liver in late pregnancy \\
\hline & Hypoxia (Anemia, cardiac failure) \\
\hline & $\begin{array}{l}\text { Hepatotoxins (Carbon tetrachloride, } \\
\text { chloroform, ether, aflatoxin) }\end{array}$ \\
\hline & $\begin{array}{l}\text { Drug induced liver cell injury } \\
\text { (methotrexate, CCl } \\
\text { halothane anaesthetic, tetracycline } \\
\text { etc.) }\end{array}$ \\
\hline & Reye's syndrome \\
\hline
\end{tabular}


${ }^{1}$ Remya. E, International Journal of Ayurvedic\& Herbal Medicine 7(6) Nov.-Dec. 2017 (2948-2955)

Table No:2 Pathya \& Apathya for NAFLD

\begin{tabular}{|c|c|c|}
\hline Factor & Do's & Dont's \\
\hline Diet Control & $\begin{array}{l}\text { Eat freshly prepared food } \\
\text { Eat only when hungry and after } \\
\text { evacuation of Mala (waste products). } \\
\text { Cereals \& Pulses - Red rice, barley, } \\
\text { green gram } \\
\text { Vegetables - Bitter gourd, snake gourd, } \\
\text { drumstick, curry leaves, coriander, } \\
\text { ginger, garlic } \\
\text { Fruits - Pomegranate, orange, dry fruits } \\
\text { like risins } \\
\text { Luke warm water minimum } 8 \\
\text { glasses/day, buttermilk } \\
\text { Gruel prepared with Trikatu, } \\
\text { Panchakola }\end{array}$ & $\begin{array}{l}\text { Avoid reheated \& untimely food } \\
\text { Excessive spicy, oily, salty,sour, } \\
\text { fatty diet, pickles } \\
\text { Basmati rice, Pulses like Black } \\
\text { gram, Yellow gram, } \\
\text { Fish, Meat preparations } \\
\text { Full fat milk, curd } \\
\text { Potato, Cauliflower } \\
\text { Junk food, Aerated drinks, } \\
\text { Chocolates, Ice creams, Bakery } \\
\text { items, Artificial sweeteners, jams }\end{array}$ \\
\hline $\begin{array}{l}\text { Lifestyle } \\
\text { modification }\end{array}$ & $\begin{array}{l}\text { Consistent Physical exercise like brisk } \\
\text { Walking daily half an hour in fresh air } \\
\text { Yoga - Dhanuraasana, Gomukhaasana, } \\
\text { Ardhamatsy-endraasana, Bhujangasana } \\
\text { Pranayama-Kapaalabhaati }\end{array}$ & $\begin{array}{l}\text { Sedentary life style } \\
\text { Excessive \& day time sleeping } \\
\text { Smoking } \\
\text { Alcohol consumption }\end{array}$ \\
\hline
\end{tabular}

